\title{
矩形堤体列まわりの平面的な波変形の特性と 波向を制御法に関する研究
}

\author{
中村孝幸*. 長田和久**. 粟田清光***
}

\section{1. まえがき}

現在, 沿岸海域の有効利用を目的として, 各種の沖合 防波提の波浪制御効果に関する検討が進められつつあ る. しかしながら, 従来の研究では, 波浪制御として 1 次元的な波高制御効果に着目したものがほとんどで, 構 造物まわりの平面的な波変形を推定する際に重要とな る，透過波や反射波の波向き特性などは汪とんど知られ ていない。

本研究は, 離岸堤などのように構造物が直線状に配列 される場合を想定して，その波浪制御効果を波高值のみ ならず波向き特性をも考慮して総合的に検討するもので ある.この際, 特に堤体間の開口長や堤体の傾斜配置角 などの配列条件に伴う透過波高やその方向分布の変動特 性などを明らかにする。そして，これらの結果に基づ き, 透過波の主卓越波向きを入射波のそれより変化でき るような堤体の配列法, 寸なわち波向き制御に有効な堤 体の配列法についても究明する.

\section{2. 平面的な波变形の算定法と評価法}

\section{（1）波变形の算定法}

本研究で用いた解析モデルおよび座標系は, 図一1 に 示すものである. 一定水深 $h$ の波動場中に, 直立式提体 構造物が一定間隔 $\lambda て ゙ ~ y$ 軸方向に規則的に配列されて 扣り，これに $x$ 軸と角度 $\theta$ をなして平面波が作用する ものとする。流体は非圧縮珄完全流体で, 波動運動は, 微小振幅波理論により表現できるものとする.

既飞中村ら（1988）は，図一1の上うな直立式徥体列 まわりの波浪ポテンシャル問題の解析法をグリーン関数 法に基づき導いている.ここでも同様な解析法を採用し て矩形是体列による波変形を算定した。この解析法によ

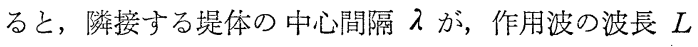
との関係で，次式を満足する $|n| \geqq 1$ が存在するとき，

$$
\lambda / L \geqq|n| /(1 \mp \sin \theta) \quad(n= \pm 1, \pm 2, \cdots \text { 複合同順 })
$$

\footnotetext{
* 正会員 工博 愛媛大学助教授 工学部土木海洋工学科

** 正会員 工修 広島県土木部

**** 京都府土木部
}

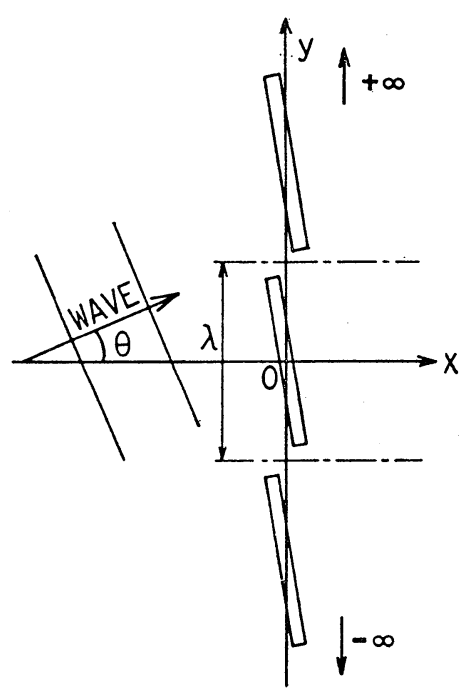

図一1 解析モデルおよび座標系

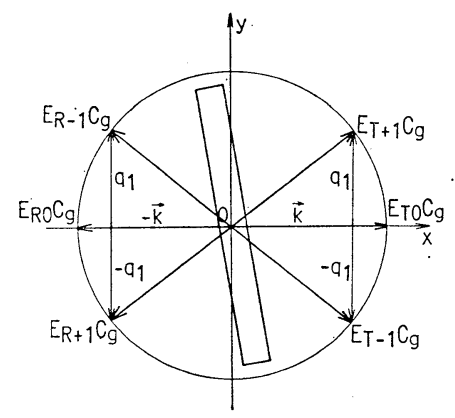

図一2 堤体列まわりの各波向き成分 $(1<\lambda / L<2$ の場合)

透過波には，入射波と同方向に伝播する成分波（直進行 波成分と称する）のみならず，それと異なる方向に伝播 する成分波（斜波成分と称する）も含まれるようになる ことが明らかれされている. Dalrymple ら（1990）は, このような堤体列まわりでの斜波成分の発生を, より簡 単にホイヘンスの原理を用いて図的に説明している.

そして，図一1のような堤体列まわりの透過波怙よび 反射波の平均エネルギーフラックスを各波向き成分別に その波数ベクトル $\vec{k}$ と併せて示すと図一2のようであ 
る.な初図中で注，簡単化のため作用波の入射角度 $\theta=$ $0^{\circ}$ で, さらに $n=-1,1$ の両者の及が式 (1) を満足 する条件，寸なわち入射波の方向から見て左右に 1 つゔ つ斜波成分が出現する条件が仮定してある.また，図中 で $q_{1}=2 \pi / \lambda, E_{T 0}, E_{R 0}$ : 透過波, 反射波の直進行波成 分の単位水表面積当りのエネルギー, $E_{T+1}, E_{R+1}$ : 同様 の波の第 1 次斜波成分のエネルギーで, 添字中の \pm は 左右の 斜波成分を表す. また $C_{g}$ : 群速度である. 式 (1) で等号が成立する条件は, 第 $n$ 次斜波成分が現 れるか否かの限界を示し, 第 $n$ 次の横波共振点 と呼ば れている.

\section{（2）波変形の評価法}

堤体列飞より斜波成分が発生する条件になると, 直進 行波成分と斜波成分が重合した短峰性の波面形状になる ため，単に透過・反射率などの 1 次元的な指標で波浪制 御効果を評価することが困難になる. 中村・小野 (1990) は，図一2 に示すようなエネルギー的な考察に基づき， 堤体列に上る透過波や反射波の特性を合理的核価する 方法を提案している.ここでも，同様な評価法を用いて 波高值や波向き特性などを判定しており, 以下その概略 を示す。

a） $\mathrm{rms}$ 波高比：これは，平面的に分布する波高の代 表量を表すもので, 堤体列方向に扔ける波高の rms 值 と入射波高との比で定義される，そして，上記した各波 向き別のエネルギーを用いると次式で算定される.

$$
\begin{aligned}
& K_{T}=\sqrt{\sum_{n=N-}^{N+} E_{T n} / E_{I}} \\
& K_{R}=\sqrt{\sum_{n=N-}^{N+} E_{R n} / E_{I}}
\end{aligned}
$$

ここで， $K_{T} ， K_{R}$ : それぞれ透過・反射波側に打ける $\mathrm{rms}$ 波高比，N+，N-：それぞれ式 (1) を満足する $n$ の最大值と最小佰, $E_{I}$ : 入射波の単位水面積当りのエ ネルギーである.

b）波向き着目した成分波のエネルギー比：これ は，透過波 (or 反射波) の全エネルギーに占める各波 向き成分のエネルギー比を示し, 以下の式で定義され る.

$$
\begin{array}{rr}
T_{n}=E_{T n} / E_{T} \quad(n=0, \pm 1, \pm 2, \cdots, N \pm) \\
\\
R_{n}=E_{T n} / E_{R} \quad(n=0, \pm 1, \pm 2, \cdots, N \pm \cdots \cdots \cdots \cdots \cdots \cdots
\end{array}
$$

ここで， $T_{n}, R_{n}$ : それぞれ透過・反射波の波向き別 の土ネルギー比で, $n=0$ のときが直進行波成分, $n \geqq 1$ が左斜波成分， $n \leqq-1$ が右斜波成分に対応する。また， $E_{T}, E_{R}$ ：それぞれ透過・反射波の全エネルギーで, 式 (2)，（3）の平方根中の分子の量に等しい.

このと第 $n$ 次斜波成分の波向きの角度 $\xi_{n}$ は, 透過 波に関する結果のみを示すと次式で与兄られる.

$$
\xi_{n}=\tan ^{-1}\left[\frac{k_{y}+q_{n}}{\sqrt{k^{2}-\left(k_{y}+q_{n}\right)^{2}}}\right]
$$

ここで, $k_{y}$ : 波数 $k$ の $y$ 方向成分, $q_{n}=2 n \pi / \lambda$ であ る.ただし， $\xi_{n}$ は $x$ 軸とのなす角（反時計なわりを正 とする)で定義してある.

\section{3. 波変形に関する理論的考察}

\section{（1）堤体の配列条件}

理論算定で用いた矩形堤体の平面形状は, 图一 3 亿示 すもので, 後述する実験時のものと同寸法にした，堤体 の配列間隔 入は $150 \mathrm{~cm}$ 之固定し, 入射波は配列軸の 法線方向より作用する直角入射の条件に限定した. そし て, この矩形堤体を配列軸 ( $y$ 軸) に関して角度 $\Psi=0$ $\sim 45^{\circ}$ の範囲で11種類，また隣接する堤体間の開口部を 配列軸に射影した長さ $l_{0}$ と配列間隔 $\lambda$ の比で定義され る見掛けの開口率 $\alpha$ を $30 \%$ の範囲で 4 種類（隣接 堤体が重なる場合を除く)に変化せしめた. この際, 堤 体の設置水深 $h=40 \mathrm{~cm}$, 堤体の厚さ $D=15 \mathrm{~cm}$ と一定 にしてある。

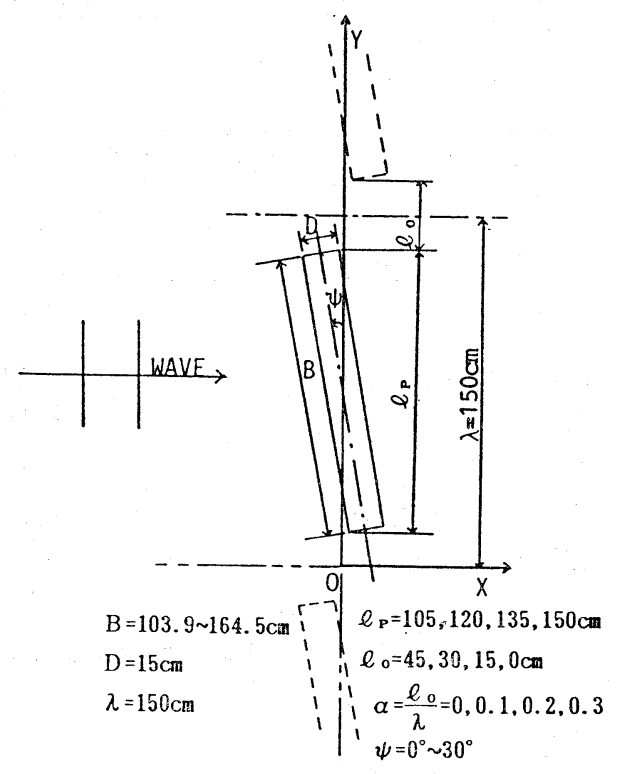

图一3 算定に用いた矩形堤体列の配置および配列状況

\section{（2）透過波の波向き特性}

図一4，5 は， $l_{p} / \lambda\left(l_{p}\right.$ : 堤体の配列軸への投影長) $=1(\alpha=0)$ の条件下で, 堤体の傾斜角 $\Psi$ がそれぞれ $12.2^{\circ}, 30^{\circ}$ のときの透過波の波向き特性量 $T_{n}$ の周期 による変化を示す, 各図中で, 第 1 横䩜には周期に関す る無次元量 $\lambda / L$, 第 2,3 横軸にそれぞれ第 1,2 次斜 波成分の波向き角度 $\left|\xi_{ \pm 1}\right|,|\xi \pm 2|$ がとってある.な拈 $\lambda / L<1$ では, 直進行波成分のみとなることから, 図中 ではこの範囲を省略してある. 


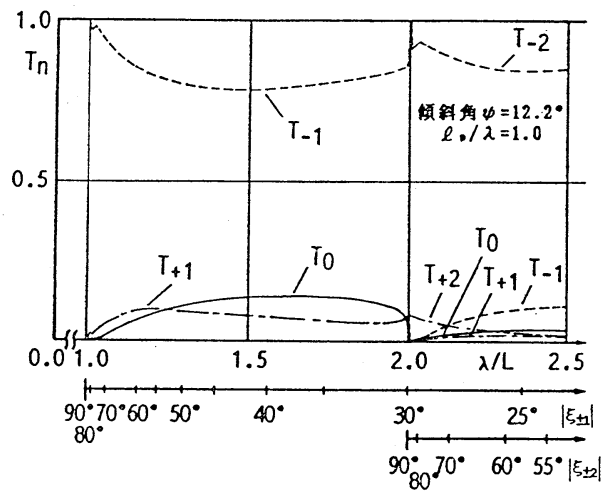

図一4 矩形堤体列背後での透過波の波向き特性 $\left(\Psi=12.2^{\circ}\right.$, $\left.l_{P} / \lambda=1.0\right)$

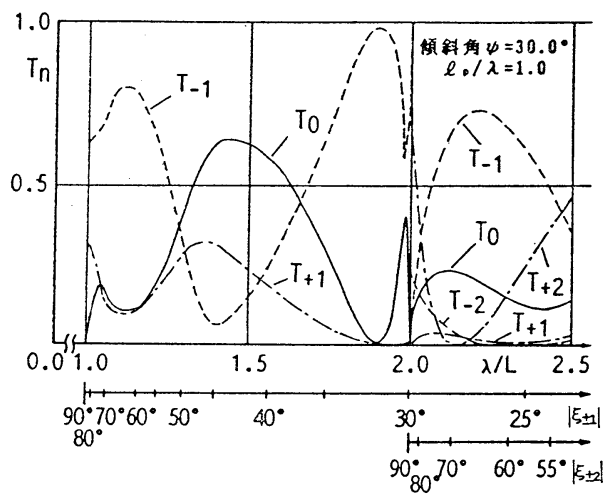

図一5 矩形堤体列背後での透過波の波向き特性 $\left(\Psi=30^{\circ}\right.$, $\left.l_{P} / \lambda=1.0\right)$

まず，これらの図の横軸を見ればわかるように， $\lambda / L$ $=1$ から 2 までの範囲で, 波向きの角度は, $90^{\circ}$ から $30^{\circ}$ をで対数関数的に变化する. このため, 堤体列によ り, ある特定の角度に, 波向きを变化させることは不可 能で, 作用波の周期条件により, その角度は異なること 飞留意する必要が㘯る，そして，これらの図より， $\Psi=$ $12.2^{\circ}$ の条件 (図一4) では, 右斜波成分 $\left(T_{-1}\right.$ or $\left.T_{-2}\right)$ が， $\lambda / N \geqq 1$ の条件下で他の成分波よりも大きく卓越す るのに対して, 堤体の傾斜角 $\Psi=30^{\circ}$ の場合, $T_{0}$ と $T_{-1}$ の卓越度が $\lambda / L$ の值によって交互に入れ替わるな ぞ，周期により卓越波の方向が変化することがわかる.

図一6は， $l_{p} / \lambda=0.8(\alpha=0.2)$ 之固定したときの右 斜波成分の総和 $\Sigma T_{-n}$ の堤体の傾斜角 $\Psi$ による変化

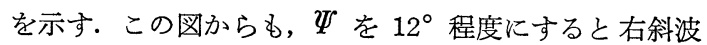
成分が広い周期帯で卓越することやこのような特性は添 ぽ $\Psi=8 \sim 17^{\circ}$ の範囲に怙いての及現れることなどが認 められる.なお，ここでは $\Psi$ が $5^{\circ}$ 以下と小さなのと きの結果を示さなかったが，このよらな傾斜角の条件で は左右の斜波成分が同程度の大きさになることなどを確 認している. 一方, 図一4,6 の比較から, 見掛けの開

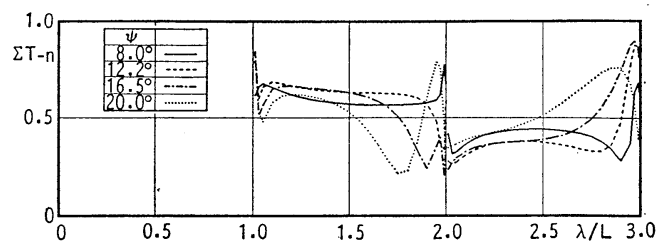

図一6 各傾斜角における右斜波成分のエネルギー比 $\left(l_{P} / \lambda\right.$ $=0.8$ )

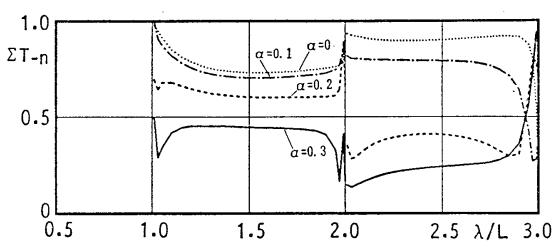

図一7 各開口率における右斜波成分のエネルギー比 $(\Psi=$ $10^{\circ}$ )

口率を大きくすると, 特に $\lambda / L>2$ の範囲で右斜波成分 の卓越度が減少することも分かる. このことは, 右斜波 成分の卓越度が顕著になる傾斜角 $\Psi=10^{\circ}$ に固定して, 傾斜角による $\Sigma T_{-n}$ の変化を示す図一7 からも分か る.

以上の検討より, 矩形堤体を傾斜して配置すると透過 波の主卓越波向きを入射波のそれより変化できることや そのときの傾斜角度としては $8 \sim 17^{\circ}$ の範囲が効果的で あることなどが理論的に推測される。

\section{（3）透過波の波高特性}

図-8 は, 図一 4,5 に対応する $l_{p} / \lambda=1(\alpha=0)$ の ときの透過波側で $\mathrm{rms}$ 波高比 $K_{T}$ の結果を示す．この 眓より， $K_{T}$ は $\Psi=12.2^{\circ}$ のとき $\lambda / L$ による变化があ まり見られず，ほぼ 0.4 程度と一定值を示すことがわか る. 一方, 堤体の傾斜角 $\Psi$ が $30^{\circ}$ の場合, 堤体の配列 方向から見た開口幅は増大するため， $K_{T}$ は 1 程度にな るときもあり， $\lambda / L$ による変動が大きくなっている、こ れは, 図一 5 に示すように, この傾斜角の条件下で透過 波の卓越方向が $\lambda / L$ により変化することが原因と考光

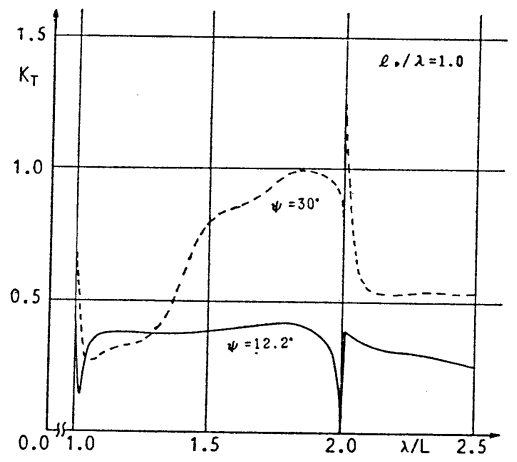

図-8 透過波側での $\mathrm{rms}$ 波高比 $K_{T} \quad\left(l_{P} / \lambda=1.0\right)$ 


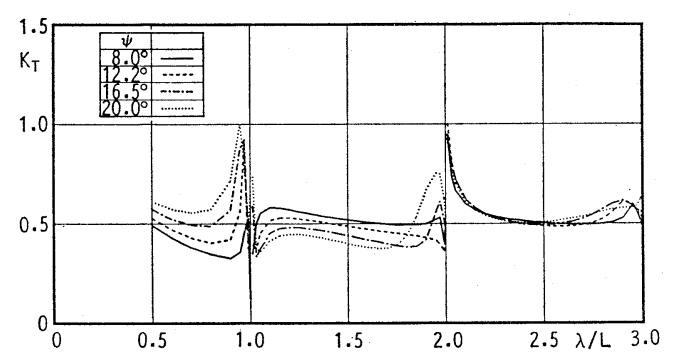

図一9 各傾斜角における透過波側での $\mathrm{rms}$ 波高比 $\left(l_{P} / \lambda=\right.$ 0.8 )

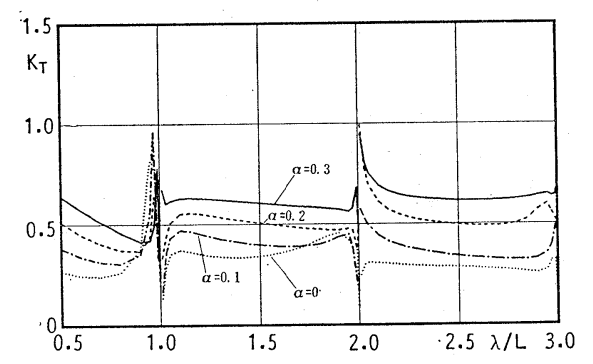

図一10 各開口率における透過波側での $\mathrm{rms}$ 波高比 $K_{T}$ $\left(\Psi=10^{\circ}\right)$

られる。

図一9，10 は，それぞれ図一6，7 に対応する条件下 での $K_{T}$ の結果を示す. これらの図より， $K_{T}$ は右斜波 成分の卓越する $\Psi=8 \sim 17^{\circ}$ の範囲では, 横波共振点付 近を除き $\lambda / L$ による顕著な変動は見られず, ほぼ 0.5 程度と一定値を示すことや，見掛けの開口率 $\alpha$ を大き くすると $K_{T}$ は増加することなどが分かる，また，図一 9 に見られるように，右斜波成分の卓越する $1<\lambda / L<2$ の範囲では, 傾斜角が小さな $\Psi=8^{\circ}$ の条件で $K_{T}$ は最 大になることなどの特性も認められる.

\section{4. 実験結果と算定結果の比較}

\section{（1）実験装置および実験方法}

実験は, 図一11 に示すよらな平面水槽を用いて行っ た.この水槽内には, 隔壁板で幅 $1.8 \mathrm{~m}$ の長水路を設 け，堤体列への入射波が正確に測定できるようにした。 そして, 水槽の終端側には, 壁面からの再反射が生じな いよらに，砕石斜面よりなる消波工を設けた。また，堤 体列による透過波执よび反射波に含まれる斜波成分が， 水槽側面より再反射しないように, 水槽側壁にも金網と 砕石よりなる消波工を設置した，模型の矩形堤体は，防 水ベニア板により同一寸法のものを 5 基製作し，これら の堤体を, 注ぼ水路の中央部に造波板と平行となるよう に直線的に配列した. この際, 隣接する堤体の中心間隔 $\lambda$ は $150 \mathrm{~cm}$ と固定し, $\alpha=0,20 \%$ の 2 種類, $\Psi$ は 0 $30^{\circ}$ の範囲で 6 種類を採用した.

実験では，計 9 本の波高計を使用し，これらの中の 2

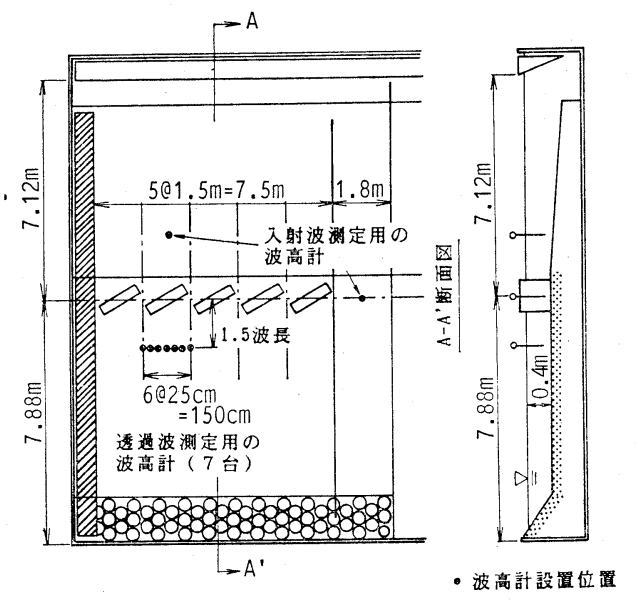

図一11 実験水槽および実験装置の概略

本は入射波の測定に，また残りの 7 本は，透過波側での 波高比の $\mathrm{rms}$ 值和よび透過波の波向き特性量の測定に 用いた. この際, rms 波高比の推定および波向きの分解 には，中村・小野（1990）による方法を採用した．そし て，上記した 7 本の波高計は，隣接する堤体の中心間隔 $\lambda$ にわた， $25 \mathrm{~cm}$ の等間隔で是体配列方向に直線的に 設置した.

堤体に作用せしめた入射波の周期 $T$ は， $0.6 \sim 1.4 \mathrm{sec}$ の範囲の 14 種類, 入射波の波高 $H$ は約 $4 \mathrm{~cm}$ と一定に し, 水深 $h$ も $40 \mathrm{~cm}$ と固定した.

\section{（2）波向き制御効果}

図一12，13 は，それぞれ $\Psi=12.2^{\circ} ， 30^{\circ}(\alpha=0 \%$, $\left.l_{p} / \lambda=1.0\right)$ の場合の透過波の 波向さ特性に関する実験 結果と算定結果の比較を示すもので, 代表例として右斜 波成分 $T_{-n}$ のみが表示してある. $\Psi=12.2^{\circ}$ の場合, 実験值と算定值は， $\lambda / L=1$ の横波共振点近傍で差異が 見られるものの, この共振点付近を除けば, ほぼ一致し ている. そしてこの場合, 右斜波成分の $T_{-1}$ が $\lambda / L$ の 広い範囲で 0.8 程度と大きく卓越することが実験的にも 確認され, 堤体列により透過波の主卓越方向を入射波の それより変化できることがわかる．共振点近傍での差異

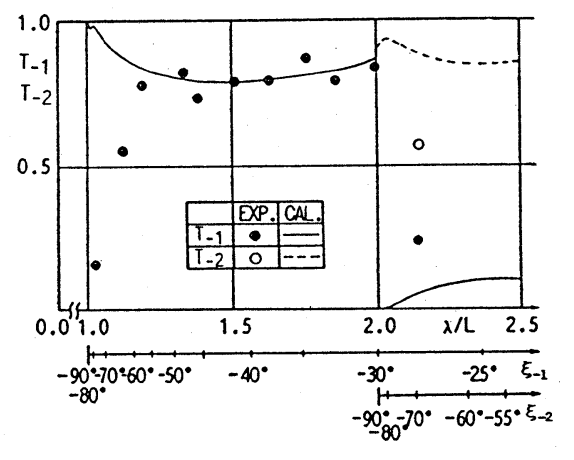

図-12 透過波中の右斜波成分 $\left(\Psi=12.2^{\circ}, l_{P} / \lambda=1.0\right)$ 


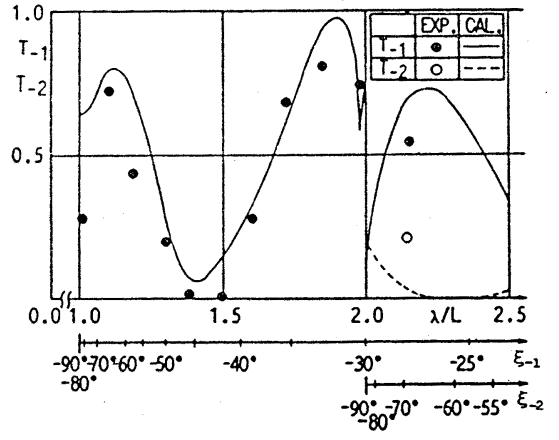

図-13 透過波中の右斜波成分 $\left(\Psi=30^{\circ}, l_{P} / \lambda=1.0\right)$

の原因としては，波向きが $90^{\circ}$ に近く，実験で配列した 堤体の基数が十分でなかったことが挙げられる.

堤体の傾斜角 $\Psi$ が $30^{\circ}$ の 図一 13 洋着目すると, 実 験值と算定値とは, やはり $\lambda / L=1$ の横波共振点近傍で 差異が認められるものの, 右斜波成分が $\lambda / L$ により複 雑に変化するなど, 全体的な変動特性は, 両者で注ぼ一 致している. そして, 傾斜角を大きくすると, 図一12 の場合に比較して, $T_{-1}$ は, 特に $\lambda / L=1.5$ 付近で著 しく低下することなどが実験的にも確認できる.

\section{(3) 波高特性}

図一14，15 は，上記した各堤体列による透過波側で の $\mathrm{rms}$ 波高比 $K_{T}$ と反射波側でのそれ $K_{R}$ の実験結 果と算定結果の比較を示すもので, それぞれ前出の図 -12，13の条件に対応している.これらの図より, 実 験結果と算定結果は, 横波共振点付近を除けば, 堤体の 傾斜角に関係なく泳淁一致していることが認められる。 そして, 是体の傾斜角 $\Psi$ が $12.2^{\circ}$ の図一14を見る と, $K_{T}$ は $\lambda / L$ の值にかかわらずほぼ 0.4 程度以下で あることなどが実験的にも確認できる、このことから， 矩形堤体を $\Psi=12^{\circ}$ 程度で, しかも $l_{p} / \lambda=1.0$ の条件 で配列すると，上述した波向き制御に加光，透過波高の 制御も西る程度行えることがわかる。 また，傾斜角 $\Psi=$

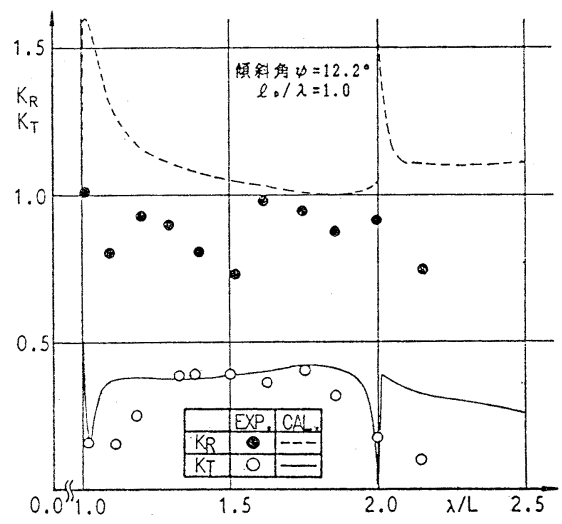

図-14 $\mathrm{rms}$ 波高比 $K_{R}, K_{T}\left(\Psi=12.2^{\circ}, l_{P} / \lambda=1.0\right)$

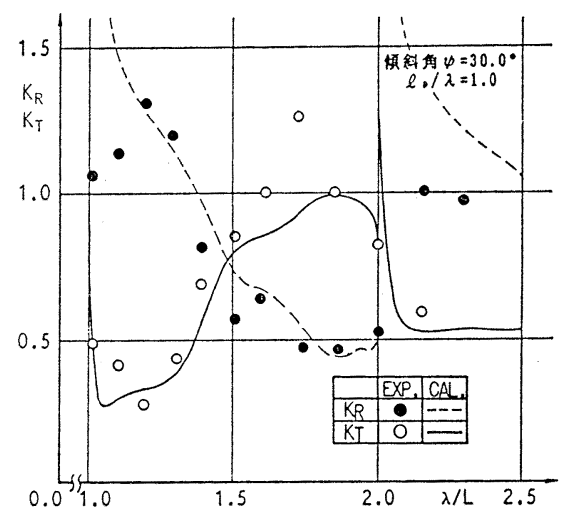

図-15 $\mathrm{rms}$ 波高比 $K_{R}, K_{T}\left(\Psi=30^{\circ}, l_{P} / \lambda=1.0\right)$

$30^{\circ}$ で $l_{p} / \lambda=1.0$ の条件（図一15）では，右斜波成分 の卓越する $\lambda / L=1.1$ 付近で, $K_{T}$ は $0.3 \sim 0.4$ 程度で あるが，右斜波成分が再度卓越する $\lambda / L=1.8$ 付近で は，0.9 以上と波高制御効果は活とんぞ期待できないも のになっている.

\section{5. 結 語}

（1）規則的配列された矩形堤体まわりの平面的な波 変形は, 堤体の配列方向に和ける波高比の $\mathrm{rms}$ 值と方 向スペクトルと頑似した概念注りり定義される各波向き 成分のエネルギー比の両者を用いて的確に評価でき，こ れらの特性量は, 堤体の配列条件を考慮した波浪境界值 問題の解析法によりほ涪推定できる.

（2）矩形提体列背後での透過波の主卓越波向きは， 堤体を配列軸より傾斜して配置すると入射波のそれより 変化させることができる，そしてその傾斜角度を配列軸 に対して 8 $17^{\circ}$ 程度の範囲汇設定すると, 波向き制御 効果は広い周期带にわたり安定して現れる.

（3）堤体列による波高制御効果は, 同一の傾斜角度 では, 開口率が小さくなる汪ど顕著になる。しかし, 波 向きの制御効果が有効な傾斜角の範囲内では, 波高制御 効果は傾斜角度化より汪とんど変化せず，乙かも作用波 の周期による变動も少ない.

\section{参 考 文 献}

中村孝幸・小野正覑 (1988)：規則配列された沖合消波堤学わ りの波浪共振の特㤬とその解析法, 第 35 回海岸工学講演会 論文集, pp. 527-531.

中村孝幸 · 小影正順 (1990)：波向き特性を考慮した堤体列ま わりの平面的な波変形の評価法について, 海岸工学論文集, 第 37 巻, pp. 534-538.

Dalrymple, R. A. and P. A. Martin (1990): Wave diffraction through offshore breakwaters, J. of Waterway, Port, Coastal, and Ocean Eng., ASCE, Vol. 116, No. 6, pp. $727-741$. 